\title{
Business Model: A Literature Review and Real Life Case
}

\author{
Xiaolong Qiao Zhan Wang* \\ Shanxi University, 92 Wucheng Road, Taiyuan city, Shanxi Province, 030006, China
}

\begin{abstract}
The importance of business model has already been identified. However, the understanding of business model in academic area is stilly overlooked. This study clarifies the definition and business model at the macroscope level with the "role + purpose" regulation, and points out four elements of business model at microscope level. The real-life case in term of the Apple Company's "hardware + software + service" business model demonstrate the four elements of a successful business model to obtain sustainable performance for firms.
\end{abstract}

Keywords: Business model, literature review, macroscopic/microscopic perspective, Apple inc,

DOI: $10.7176 / \mathrm{EJBM} / 11-32-03$

Publication date: November $30^{\text {th }} 2019$

\section{Introduction}

Nowadays, the competitions among firms are actually not concerning their products, but their business model (Drucker 1994). Thus, how firms do business is more important than what they do. Firms can create much more value via a great business model within a mediocre technology than a great technology exploited with a mediocre business model (Chesbrough 2010). A firm must find an appropriate business so that it can capture value from its products and services. Considering successful firms like Apple and Google, their innovative business models have gradually showed their excellent performances. However, in academic area, the business model is still poorly understood. The term "business model" appeared in academic article for the first time in 1957 (Bellman et al. 1957) and in the title and abstract of a journal article in 1960 (Gardner 1960). Business model, however, became a new and independent research field that emerged at the 1990s based on the popularization of the Internet. Moreover, with the success of Amazon and Dell, business model has risen to prominent field in current days. However, the definition of business model is seldom defined explicitly. In academic article, there are almost as many definitions as there are authors. This study is trying to bring the clarity to business model in two different levels in terms of macro level and micro level, ranging from general definition to list of elements. In the macroscopic perspective, "role + purpose" regulation is promoted in order to state the broader understanding of concepts of business model. While in the microscopic perspective, this study points out four elements, customer value proposition, four market forces, resource and capability, and profit formula to through comparing and contrasting the components mentioned by different authors. Moreover, a reallife case regarding the successful business model is demonstrated. Lastly, this study provides some suggestions for future study regarding business model.

\section{Literature Review}

2.1 Definitions of business model at the macroscopic perspective

From a linguistic perspective, the business model is a compound word, both business and model have the specific meaning by themselves. The word business has been interpreted as "the activity of making money by producing or buying and selling goods, or providing services", and the word model as "a representation that shows how the system or process works, and what it looks like". Putting these two words together, it is concluded that business can be treated as the purpose of business model, while model can be regarded as the role of business model in doing business. A method to give a definition of a word is headword pluses key qualifier. We treat business model's role as headword, and purpose as key qualifier.

Thus, the definitions of business model in the macroscopic perspective are abided by this "role + purpose" regulation. Different authors give different words to the role of business model, like system (Amit and Zott 2001), Logic (Teece 2010, Casadesus-Masanell and Ricart 2010) and framework (Chesbrough and Rosenbloom 2002), and so forth. But for the purpose of business model, theirs are much more unified, that is, create, deliver and capture value (Baden-Fuller and Morgan 2010, Teece 2010, Gambardella and McGahan 2010, Amit and Zott 2001), and generate revenue (Gambardella and McGahan 2010, Chesbrough and Rosenbloom 2002). Table 1 shows definitions of business model in macroscopic perspective by different authors through "role + purpose" regulation. 
Table 1. Concept of business model followed by "role + purpose" regulation

\begin{tabular}{|l|l|l|}
\hline Authors & \multicolumn{1}{|c|}{ Role } & \multicolumn{1}{c|}{ Purpose } \\
\hline (Amit and Zott 2001) & A unifying unit of analysis & Captures the value creation \\
\hline (Zott and Amit 2010) & $\begin{array}{l}\text { A system of interdependent } \\
\text { activities }\end{array}$ & $\begin{array}{l}\text { Transcends the focal firm and spans its } \\
\text { boundaries }\end{array}$ \\
\hline (Teece 2010) & $\begin{array}{l}\text { Logic, data and other } \\
\text { evidence }\end{array}$ & Creates and delivers value to customers \\
\hline $\begin{array}{l}\text { (Chesbrough and } \\
\text { Rosenbloom 2002) }\end{array}$ & Design and architecture & Value creation, delivery and capture \\
\hline $\begin{array}{l}\text { (Baden-Fuller and Morgan } \\
\text { 2010) }\end{array}$ & $\begin{array}{l}\text { A set of generic level } \\
\text { descriptors }\end{array}$ & $\begin{array}{l}\text { Converts technology through customers and } \\
\text { markets into economic output. }\end{array}$ \\
\hline $\begin{array}{l}\text { (Casadesus-Masanell and } \\
\text { Ricart 2010) }\end{array}$ & Logic of firm & Create and distribute value \\
\hline $\begin{array}{l}\text { (Brandenburger and Stuart } \\
1996)\end{array}$ & An organization's approach & Generate revenue \\
\cline { 2 - 3 } & Assumption & Create and capture value \\
\hline
\end{tabular}

Based on the literature synthesis, the following definition is proposed for buseinss model in macroscopic perspective through "role + purpose" regulation:

A business model is a description of how business is done in order to generate sustainable value.

\subsection{Definitions of business model at the microscopic perspective}

A growing number of researchers define business model in microscopic perspective by listing elements that belong into a business model (See Table 2). By comparing and contrasting the components of business model from different authors, four fundamental elements have emerged that cover the most common components from the synthesis, that is value proposition, four market forces, capability and resource, and profit formula. Each of these elements is considered below.

2.2.1 Customer value proposition

A customer value proposition gives an overall view of values which a company can offer to costumers, and shows the way to create value for customers through the products and services fundamentally (Demil and Lecocq 2010). The customer value proposition is the starting point of business model design. It is impossible to create a business model without identifying a clear customer value proposition based on customer requirement analyses. The customer value proposition contains several points, such as customers' needs, products and services which can meet customers' satisfaction, the way the products and services are sold, and products' value from customer's perspective. It has been discovered that customer value proposition is composed of three aspects: targeting the customers; identifying the job to be done (fulfill the important needs for target customers); and offering a way to fulfill these needs (Johnson et al. 2008).t

2.2.2 Four market forces

Figure 1 shows the relationship of the four market forces, that is, suppliers, channels, target customers and coopetition. This model's frame is based on the Michael Porter's Five Forces Model and adds the perspective of cooperation in it. The model of four market forces (Figure 1) emphasizes the interactive and interdependent relationship. Suppliers are the firm's operational bases. It is through channels that the firm gets supplies for materials and manufacturing from suppliers, and delivers the value to customers (Osterwalder and Pigneur 2010).

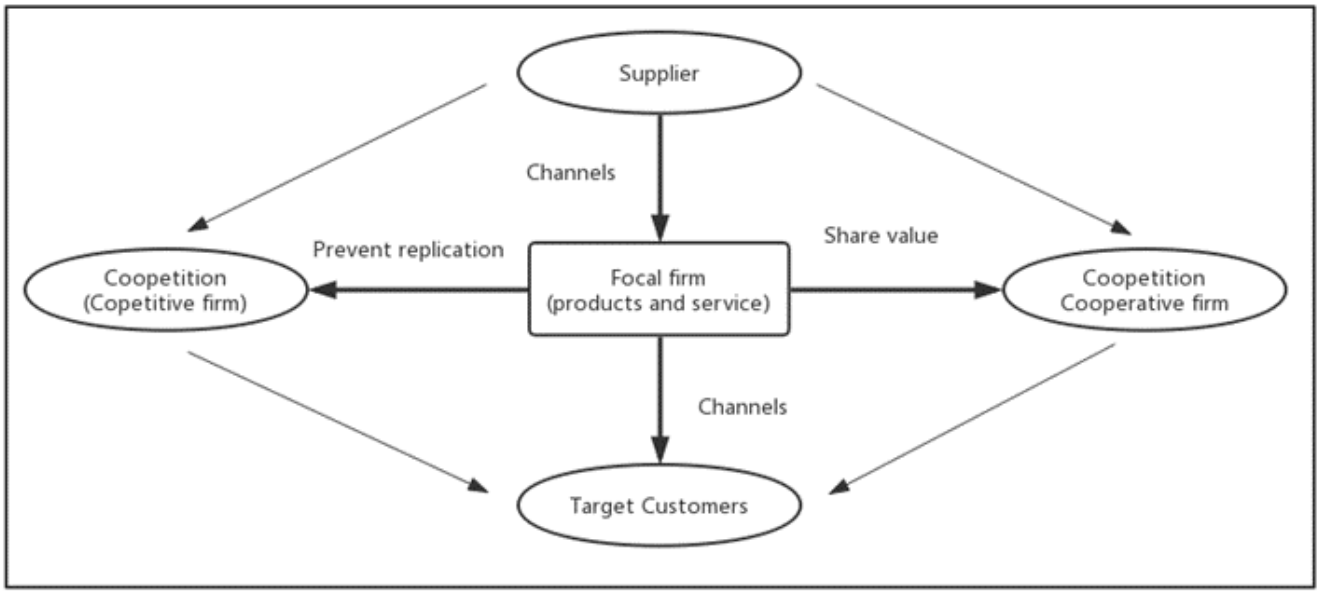

Figure 1 The model of four market forces 
The term coopetition describes two or more firms that can compete and cooperate in the market simultaneously (Luo 2007, Bengtsson and Kock 2000). Through cooperative relationship, the focal firm works together with other firms, for example, two or more firms creates a complementary brand to enhance performance collectively by sharing resources and committing to common goals, and to share value finally. Meanwhile, the focal firm must take independent action in other domains to improve their own performance and develop barriers to make the business model difficult to imitate when the firm competes with existing counterparts, potential new entrants, and substitute producers (Teece 2010, Luo 2007).

The suppliers and coopetition are focus on the focal firm' products and services, and the products and services are customer-centric. Also, it is channels that create the interactive relationship among these forces. Thus, the suppliers, products and services of focal firm and target customers will be the common thread of business model, and channels provide ways to the firms to get in touch with the suppliers and customers, in addition, the coopetition develops and enriches the business model. So the model of four market forces will be the basic frame of business model.

2.2.3 Capability and resource

Capability and Resource describe the intangible and tangible assets such as people, technology, equipment, channels, brand and so forth (Johnson et al. 2008) which is the material basis that can make a business model work. Capability and resource are the basic condition that can interact with other three elements of business model and allow an enterprise to create and offer a value proposition, achieve the optimum situation analyzed in four market forces, and make the business model feasible to deliver value to customer and company (Demil and Lecocq 2010).

\subsubsection{Profit formula}

The profit formula describes how the company creates and captures value for itself (Teece 2010). It contains of revenue model - how much money can be made, and cost structure-how costs are allocated (Johnson et al. 2008).

Table 2 The elements propose by different authors the relation with the four elements

\begin{tabular}{|c|c|c|c|c|}
\hline Four Elements & $\begin{array}{l}\text { Value } \\
\text { proposition }\end{array}$ & Four market forces & $\begin{array}{l}\text { Capability and } \\
\text { resource }\end{array}$ & Profit formula \\
\hline $\begin{array}{l}\text { Amit and Zott } \\
(2001)\end{array}$ & $\begin{array}{l}\text { Customer- } \\
\text { centric }\end{array}$ & Network effect & $\begin{array}{l}\text { Resources and } \\
\text { ability }\end{array}$ & Not mentioned \\
\hline Teece (2010) & $\begin{array}{l}\text { What customers } \\
\text { want }\end{array}$ & How customers want it & $\begin{array}{l}\text { How the firm } \\
\text { can achieve }\end{array}$ & Get paid, make a profit \\
\hline $\begin{array}{l}\text { Chesbrough } \\
(2010)\end{array}$ & $\begin{array}{l}\text { Value } \\
\text { proposition }\end{array}$ & $\begin{array}{l}\text { Market segment, position } \\
\text { of firm, competitive } \\
\text { strategy }\end{array}$ & Capability & $\begin{array}{l}\text { Revenue generation, } \\
\text { cost structure, profit } \\
\text { potential }\end{array}$ \\
\hline $\begin{array}{l}\text { Baden-Fuller and } \\
\text { Morgan }(2010)\end{array}$ & Customer & Market and products & $\begin{array}{l}\text { Resources and } \\
\text { capability }\end{array}$ & Not mentioned \\
\hline $\begin{array}{l}\text { Demil and Lecoq } \\
(2010)\end{array}$ & Not mentioned & Value delivery & $\begin{array}{l}\text { Resource and } \\
\text { competences }\end{array}$ & Not mentioned \\
\hline $\begin{array}{l}\text { Johnson et al. } \\
\text { (2008) }\end{array}$ & $\begin{array}{l}\text { Customer value } \\
\text { proposition }\end{array}$ & Not mentioned & Key resources & Profit formula \\
\hline $\begin{array}{l}\text { Itami and Nishino } \\
(2010)\end{array}$ & Not mentioned & Business system & Not mentioned & Profitable model \\
\hline $\begin{array}{l}\text { Mason and Spring } \\
\text { (2011) }\end{array}$ & Not mentioned & Marketing network & Technology & Not mentioned \\
\hline $\begin{array}{l}\text { Shin and Park } \\
(2009)\end{array}$ & Not mentioned & Strategic component & Operational level & Economic \\
\hline
\end{tabular}

Table 2 describes the elements propose by different authors and show their relation with the four elements.

Base on the literature synthesis leading to the notion of macro-level and four elements of business model, the following definition for business models is proposed:

The Business model describe how an enterprise do business through four elements-value creation, four market forces, capability and resource, and profit formula and their relationships in order to generate sustainable value.

In these four elements of the business model, the customer value proposition and the profit formula present value for the customers and the company, respectively; four market forces and resource and capability show how the value will be delivered to the customers and the company. These four elements are interlocking, every change of them can affect the others and the whole business model. 


\section{A real-life case}

To illustrate the definition of business model, this study considers the four elements related with Apple's classic business model, which can be treated as "hardware + software + service". Such business model has been firstly applied with the MP3 product in terms of iPod, that is "iPod + iTunes + iTunes Music Store", which has offered unprecedented experience to customers. The following demonstrates how the four elements together for "iPod + iTunes + iTunes Music Store".

\subsection{Value proposition}

iPod is designed as distinctive portable media player with mass storage from 10-gigabyte to 160-gigabyte that allows customers to carry at most 4000 songs with them everywhere. The iTunes Music Store is a legitimate download platform that allows customers to hold the ownership of the songs permanently through paying for $\$ 0.99$ per song to download it. In addition, it is not necessary to buy the whole album, customers can listen to the songs free for 30 seconds each in order to decide whether they want to pay for the songs, and finally create their own music library in iTunes.

\subsection{Four Market Forces}

Table 3 The four market forces of "iPod + iTunes + iTunes Music Store" business model

\begin{tabular}{|l|l|}
\hline Four Elements & "iPod + iTunes + iTunes Music Store" business model \\
\hline Supplier & $\begin{array}{l}\text { There are few suppliers of Apple can get the long-term orders. Because of great volume in } \\
\text { market, Apple has bargaining power of suppliers and usually changes the suppliers in } \\
\text { order to reduce cost. }\end{array}$ \\
\hline Target Customer & $\begin{array}{l}\text { Middle- and high- end customers, people who pure fashion, loyal followers of Apple's } \\
\text { product }\end{array}$ \\
\hline Channel & $\begin{array}{l}\text { Record Company: Sony Music, Universal Music Limited, EMI, UEA, and Rock Records } \\
\text { provide music and music and music videos for the iTunes Store. } \\
\text { Film producer: Sony Picture Movies, Pixar Animation Studio, Universal Picture, and } \\
\text { Warner Bros and so forth. } \\
\text { Other content producer: TV shows and podcasts. } \\
\text { Other cooperate partner: Nike }\end{array}$ \\
\hline Coopetition & $\begin{array}{l}\text { The companies that in the same industry like Sony and Samsung, and that manufacture } \\
\text { substitute products include iPhone, and the new entrants. }\end{array}$ \\
\hline
\end{tabular}

\subsection{Resource and capability}

Apple's brand is Apple's brand: one of the most value brands in the world. Regarding to the ability of technology innovation, the iPod leads to iPhone and iPad, the iTunes Music Store leads to the App Store that mainly support iPhone and iPad. Regarding to the ability of business model innovation, the business model of iPhone in terms of "iPhone + iPod's business model + Mobile me + App Store + Telecom operators" and the business model of iPad in terms of "iPad + iPod's business model + iMac System + App Store " is the upgraded of the business model of iPod.

\subsection{Profit formula}

An iPod's (30-gigabyte) retail price is $\$ 299$, wholesale price is $\$ 224$, and the total cost is $\$ 144$, so Apple made $\$ 80$ in gross profit of iPod. In addition, iTunes Music Store has the revenue streams for Apple.

\section{A real-life case}

It is no surprise but should be remedied that great technology achievements fail commercially because little attention has been given to a business model to take them to market properly. From an academic point of view, the term business model is frequently mentioned, but rarely analyzed, and it is seldom defined explicitly (Teece 2010, Chesbrough and Rosenbloom 2002). First and foremost, having clear definitions of the business model is a necessary condition to do the research (Casadesus-Masanell and Ricart 2010). Secondly, real life cases for well know business model in some industries should be identified progressively (Zott and Amit 2010). Business scholars repeatedly study the same cases: South-West Airlines, Google, and Xerox etc., to create a deep understanding of how that kind of business model works, both in theory and in practical details (Baden-Fuller and Morgan 2010). Finally, some scholars give more practical suggestions. Casadesus-Masanell and Ricart (2010) suggest that having an integrative framework that cleanly separate the realms of strategy, business models and tactics, and illustrate how they interconnect and affect each other will be the practitioners' hope that can guide business model designing and implement (Casadesus-Masanell and Ricart 2010). Amit and Zott (2010) conceptualize the business model as a system of interdependent activities, and suggest that scholars could draw on activity theory to further explore the relationship between "individual action, organizational activities and 
business model". The forces that facilitate and impede the search for constructive adaptation in the elements of an extant business model would also be proposed in future study (Chesbrough and Rosenbloom 2002).

\section{References}

Amit, R. and Zott, C. (2001) 'Value creation in E-business', Strategic Management Journal, 22(6-7), 493-520.

Baden-Fuller, C. and Morgan, M. S. (2010) 'Business Models as Models', Long Range Planning, 43(2-3), 156171.

Bellman, R., Clark, C. E., Malcolm, D. G., Craft, C. J. and Ricciardi, F. M. (1957) 'On the Construction of a Multi-Stage, Multi-Person Business Game', Operations Research, 5(4), 469-503.

Bengtsson, M. and Kock, S. (2000) "'Coopetition" in business networks - to cooperate and compete simultaneously', Industrial Marketing Management, 29(5), 411-426.

Brandenburger, A. M. and Stuart, H. (1996) 'Value-based business strategy', Journal of Economics \& Management Strategy, 5(1), 5-24.

Casadesus-Masanell, R. and Ricart, J. E. (2010) 'From Strategy to Business Models and onto Tactics', Long Range Planning, 43(2-3), 195-215.

Chesbrough, H. (2010) 'Business Model Innovation: Opportunities and Barriers', Long Range Planning, 43(2-3), 354-363.

Chesbrough, H. and Rosenbloom, R. S. (2002) 'The role of the business model in capturing value from innovation: evidence from Xerox Corporation's technology spin-off companies', Industrial and Corporate Change, 11(3), 529-555.

Demil, B. and Lecocq, X. (2010) 'Business Model Evolution: In Search of Dynamic Consistency', Long Range Planning, 43(2-3), 227-246.

Drucker, P. F. (1994) 'The Theory of the Business', Harvard Business Review, 72(5), 95-104.

Gambardella, A. and McGahan, A. M. (2010) 'Business-Model Innovation: General Purpose Technologies and their Implications for Industry Structure', Long Range Planning, 43(2-3), 262-271.

Itami, H. and Nishino, K. (2010) 'Killing Two Birds with One Stone Profit for Now and Learning for the Future', Long Range Planning, 43(2-3), 364-369.

Johnson, M. W., Christensen, C. M. and Kagermann, H. (2008) 'Reinventing Your Business Model', Harvard Business Review, 86(12), 50-+.

Luo, Y. D. (2007) 'A coopetition perspective of global competition', Journal of World Business, 42(2), 129-144.

Mason, K. and Spring, M. (2011) 'The sites and practices of business models', Industrial Marketing Management, 40(6), 1032-1041.

Osterwalder, A. and Pigneur, Y. (2010) Business Model Generation, New Jersey: John Wiley \& Sons, Inc.

Teece, D. J. (2010) 'Business Models, Business Strategy and Innovation', Long Range Planning, 43(2-3), 172194.

Zott, C. and Amit, R. (2010) 'Business Model Design: An Activity System Perspective', Long Range Planning, 43(2-3), 216-226. 